\title{
1 Changes in the soluble nitrogen fraction of milk throughout PDO Grana Padano
}

\section{cheese-making}

3 Luisa Pellegrino ${ }^{a *}$, Veronica Rosi $^{a}$, Paolo D’Incecco $^{a}$, Angelo Stroppa $^{b}$, John A. Hogenboom ${ }^{a}$

4

${ }^{a}$ Department of Food, Environmental and Nutritional Sciences, University of Milan, via Celoria 2, 5 I-20133 Milan, Italy

${ }^{b}$ Consorzio di Tutela del Formaggio Grana Padano DOP, I-25010 San Martino d/Battaglia (BS), Italy

*Corresponding author. Tel +390250316668

E-mail address: luisa.pellegrino@unimi.it

\section{ABSTRACT}

The behavior of soluble nitrogen compounds during Grana Padano cheese-making was studied at eight dairies. Raw milk, skimmed milk, sweet whey and the derived natural whey culture, collected from 24 processes, were analyzed for soluble whey proteins ( $\alpha$-La and $\beta$ - $L g$ ), proteose-peptones (PP), small peptides (SP), caseinomacropeptides (CMPs), and free amino acids (FAA). The PP fraction increased during milk natural creaming, then part of it was selectively retained in the curd and the rest degraded in the first few hours of whey fermentation, together with $\alpha$-La, CMPs and part of SP. Features outlined for the whey culture have been confirmed on 30 samples collected at six different dairies. A time course study of the whey fermentation showed that degradation of $\alpha$ La begins when the $\mathrm{pH}$ drops below 4, whereas $\beta$-Lg content did not change. Uptake of specific FAA is shown to support the initial growth of lactic acid bacteria in whey. 


\section{Introduction}

Grana Padano PDO cheese is manufactured in a defined geographical area of northern Italy using the traditional process described in the product specification (European Parliament and Council, 2012). Holstein-Friesian cows make up almost $95 \%$ of the dairy herds providing milk for Grana Padano manufacture. Corn silage represents the most important part of the cows' diet all year round, whereas some differences may exist in concentrate supplementation, depending upon the season (Borreani et al., 2013).

Raw milk is regularly collected at farms within $12 \mathrm{~h}$ after milking and, notwithstanding hygiene prescriptions (European Commission, 2004), must not be cooled below $8^{\circ} \mathrm{C}$ since refrigeration decreases both natural creaming and rennet coagulation suitability, and alters the native microbial balance (Caplan et al., 2013; Montel et al., 2014; Raats et al., 2011). At the dairy, milk is partly skimmed by natural creaming, then transferred to a traditional copper vat; natural whey starter is added and coagulation occurs at $32-33^{\circ} \mathrm{C}$. The curd is cut into very small granules, cooked to $53-$ $56^{\circ} \mathrm{C}$ and left to compact at the bottom of the vat for $40-60$ min before extraction and molding. Part of the whey (at $\mathrm{pH}$ 6.2-6.4) is taken from the vat and incubated to obtain the natural whey starter for cheese-making the next day. The whey starter for Grana Padano (titratable acidity 28$30{ }^{\circ} \mathrm{SH}$ per $50 \mathrm{~mL}, \mathrm{pH}$ 3.3-3.6) mainly contains thermophilic strains of lactic acid bacteria (LAB), i.e. Lactobacillus helveticus (60-80\%), Lactobacillus delbrueckii ssp. lactis plus Lactobacillus delbrueckii ssp. bulgaricus (10-40\%), and Streptococcus thermophilus (1-20\%), with a total count in the order of 8-9 log cfu mL ${ }^{-1}$ (Rossetti et al., 2008; Santarelli et al., 2008; Cremonesi et al., 2011). Other wild strains, including some heterofermentative species such as Lactobacillus fermentum, Lactobacillus rhamnosus, Lactobacillus casei, Pediococcus acidilactici, represent minor species, commonly considered as nonstarter LAB (NSLAB) (Gatti et al., 2014). The cheese curd is kept in a mold for 48 
$47 \mathrm{~h}$ to allow cooling and acidification by LAB fermentation before $18-20 \mathrm{~d}$ of salting in brine. All of

48

49

50

51

52

53

54

55

67

these steps are very well characterized in their microbiological (Giraffa et al., 1998; Gatti et al., 2006) and technological features (Pellegrino et al., 1997).

Several analytical parameters currently adopted in identity assessment and quality control of Grana Padano cheese on the retail market are based on these studies (Cattaneo et al., 2008; Masotti et al., 2010). In contrast, much less attention has been paid to clarifying how the complex microbiota of raw milk affects milk components throughout the cheese-making process. In particular, very few studies have been dedicated to investigating how milk components change during natural creaming and in-vat working, or how whey components change during fermentation (Bosi et al., 1990). Considering the nutritional requirements of LAB, besides lactose, the soluble nitrogen compounds (SNCs) represent the most important source of energy for growth.

This paper investigates how the soluble nitrogen fraction of raw milk is modified throughout milk pre-treatment and in-vat working and during the subsequent fermentation of the cheese whey in the manufacture of Grana Padano. This knowledge is interesting for cheese in general but acquires particular relevance in the case of hard cheeses, whose manufacturing process (from milk arrival at the dairy to curd molding) may last up to 20-24 h. For this purpose, samples were collected along the cheese-making process at different Grana Padano dairies, and the SNCs, namely individual whey proteins, peptones, peptides and free amino acids, were evaluated. Seasonal variability was considered as well. 


\section{Materials and methods}

\subsection{Milk, whey and whey culture samples}

A total of 24 cheese manufacturing processes were studied at eight dairies of the Consorzio di Tutela del Formaggio Grana Padano DOP in different periods of the year (i.e. late spring-summer and late autumn-winter). The same sampling procedure was strictly followed. Whole raw milk (WM) was taken from the collection tank (bulk >20 tons) on arrival at the dairy, and the corresponding skimmed (fat 2.3-2.4\%) milk (SM) obtained by natural creaming was collected for coagulation. At the end of in-vat working, sweet whey (SW) was taken from the same vat after curd extraction and the derived natural whey culture (WC) was sampled after 20-22 $\mathrm{h}$ of fermentation. In addition, 30 samples of WC were collected on different days from six other dairies of the Grana Padano production area and analyzed. Finally, at one of the involved dairies, samples were taken from the whey fermentation tank at $0,1,2,3,4,6,9,12,20 \mathrm{~h}$ during the regular incubation process on two different days, while temperature and $\mathrm{pH}$ were recorded. All of the samples were immediately frozen and kept at $-20^{\circ} \mathrm{C}$ until analysis. Standard plate count (SPC) and somatic cell count (SCC) data were kindly provided by the dairies.

\subsection{Chemicals}

Pure $\alpha$-lactalbumin ( $\alpha$-La) (code L6010) and $\beta$-lactoglobulin ( $\beta$-Lg) (code L0130) and single amino acids were purchased from Sigma-Aldrich (Milan, Italy). Nynhydrin was purchased from Biochrom Ltd (Cambridge, UK). All chemicals were of analytical grade.

\subsection{Analytical methods}

Contents of soluble whey proteins, proteose-peptones (PP), caseinomacropeptides (CMPs) and small peptides (SP) were determined by HPLC in WM, SM, SW and WC samples using the same preparation procedure. The samples were adjusted to $\mathrm{pH} 4.6$ with either $2 \mathrm{~N} \mathrm{HCl}$ or $2 \mathrm{~N} \mathrm{NaOH}$, 
centrifuged (2000 $\mathrm{g}$ for $15 \mathrm{~min}$ ) and the supernatant was filtered through a $0.22 \mu \mathrm{m}$ membrane filter (Millipore, Vimodrone, Italy) before HPLC analysis. The HPLC system consisted of an Alliance module equipped with a 996 DAD detector (Waters, Milford, MA, USA) operated at $205 \mathrm{~nm}$ and the data were recorded and integrated using Empower ${ }^{\mathrm{TM}}$ software (Waters). The chromatographic column PLRP-S (250 x 4.6 mm, $300 \AA ̊$ pore size, $5 \mu \mathrm{m}$ particle size) (Varian Medical System, Milan, Italy) was kept at $40^{\circ} \mathrm{C}$. Chromatographic conditions described by the ISO Standard 13875 (2005) were adopted. The elution gradient (De Noni et al., 2007) allowed the separation of SP (eluting from 4 to $7 \mathrm{~min}$ ) and PP (from 11 to $15 \mathrm{~min}$ ) (Fig. 1). The two peaks corresponding to the nonglycosylated CMPs A and B were identified according to Thoma et al. (2006). Soluble $\alpha$-La and $\beta$-Lg were quantified by an external standard method using commercially pure proteins to obtain calibration curves in the range 100-3000 $\mathrm{mg} \mathrm{L}^{-1}\left(\mathrm{r}^{2}>0.98\right.$ for both the proteins). Quantification of PP, CMPs and SP was achieved using the calibration curve of $\alpha$-La. Free amino acids (FAA) were determined on the same filtrates after 1:1 dilution with lithium citrate buffer at $\mathrm{pH} 2.2$ and further filtration through $0.2 \mu \mathrm{m}$ filter (Millipore). The chromatographic separation was carried out on a Biochrom 30+ (Biochrom Ltd, Cambridge, UK) automatic amino acid analyzer operated under the conditions provided by the manufacturer. These employ an eight-step elution program with lithium citrate buffers of increasing $\mathrm{pH}$ and ionic strength, post-column derivatization with ninhydrin, and detection at 440 and $570 \mathrm{~nm}$. The quantification was carried out using four-level calibration lines of the 21 amino acids in the range $0.75-22.5 \mathrm{mg} \mathrm{L}^{-1}$ and using norleucine (SigmaAldrich) as an internal standard. Repeatability values of ISO Standard 13903 (2005) were fulfilled.

\subsection{Statistical analyses}

All analyses were carried out in duplicate and mean values and standard deviations were considered. Ranges and coefficients of variation (CV) were reported to express overall variability of 
115 the different types of samples for the tested parameters. Comparisons were made by Tukey's test

116

117

118

119

120

121

122

123

124

125

126

127

128

129

130

131

132 and ANOVA, and $P<0.01$ was considered significant. Statistical analyses were carried out using Minitab software (release 14, 2004; State College, PA, USA).

\section{Results and discussion}

A systematic study was firstly carried out on 24 cheese manufacturing processes to evaluate how the SNCs change through technological, enzymatic and microbiological factors. To reach this goal, we used specific analytical techniques to quantify the main constituents of SNCs with high accuracy. As we have shown in previous work (De Noni et al., 2007; Cattaneo et al. 2014), SP (MW $<10 \mathrm{KDa}), \mathrm{PP}$, as well as the main native whey proteins, can all be evaluated by HPLC in a single run (Fig. 1). The presence of CMPs could also be detected (Thoma et al., 2006) and quantified in whey samples. In addition, the pattern of FAA was systematically studied for the first time in samples of cheese milk and in the derived SW and WC. The analysis was carried out by ion exchange chromatography, since this technique proved to be more reliable than HPLC for this purpose (ISO, 2005). Data obtained for individual SNCs are summarized in Fig. 2.

3.1 Variability of soluble nitrogen composition of raw milk intended for Grana Padano cheesemaking

Amongst the whey proteins, only $\alpha$-La and $\beta$ - Lg were considered here, since these are less influenced by stage of lactation and health conditions of the cows. The coefficient of variation (CV) was $4 \%$ and $9 \%$ for the content of $\alpha$-La and $\beta$-Lg, respectively (Fig. 2 ), independent of the season (Table 1). The levels are in accordance with those reported by other authors (Schlimme et al., 1996; Wedholm et al., 2006, Stergiadis et al., 2013). As expected, a much higher variability was 
found for PP and SP, the contents of which are dependent upon enzyme activities. Although all samples were collected within $12 \mathrm{~h}$ after milking, PP levels ranged between 280 and $655 \mathrm{mg} \mathrm{L}^{-1}$ (CV 22\%) (Fig. 2). The content of PP in raw milk increases during storage as a result of the activity of plasmin on $\beta$-casein. Furthermore, the rate of increase of PP content is positively correlated with milk SCC because the complex activation system of plasminogen to plasmin is partially bound to these cells (Ismail and Nielsen, 2010). These features explain the very wide range of PP levels (500$3000 \mathrm{mg} \mathrm{L}^{-1}$ ) in raw milk reported in the literature (Pâquet 1989; Van Boekel \& Crijns, 1994; Merin et al. 2008). Data in the current study falls at the lowest end of this range, suggesting that management of milk collection in the Grana Padano system does not promote extensive plasmin activity which is detrimental to rennet coagulation. Levels of SP were in the range from 255 to 722 $\mathrm{mg} \mathrm{L}^{-1}$, with $\mathrm{CV}=28 \%$ (Fig. 2), comparable with our previous data. Noticeably, data in Table 1 show that, since raw milk is only partly cooled before collection, high temperatures in summer strongly affect variability (CV) of SP content. In contrast, PP contents shift to slightly higher levels, due to the physiologically higher values of SCC (Bertocchi et al., 2014), whereas variability does not change.

Total FAA levels were in the range $63-90 \mathrm{mg} \mathrm{L}^{-1}$, with $\mathrm{CV}=12 \%$ (Fig. 2) and, contrary to what has been observed for SP, variability was independent from the season (Table 1). These levels are comparable to those reported by Csapò et al. (1995) on Holstein cows' milk and by Mills and Thomas (1981) on cows' milk, i.e. 34 and $69 \mathrm{mg} \mathrm{L}^{-1}$ respectively. The pattern of FAA is shown in Table 2. Remarkably, glutamic acid represents $30 \%$ of the FAA on average, whereas some other amino acids (glycine, alanine, aspartic acid, arginine, glutamine, valine, lysine, proline) are present at lower levels, comparable with each other. Surprisingly, we also detected small amounts $(<1 \mathrm{mg}$ $\mathrm{L}^{-1}$ ) of FAA, namely ornithine, citrulline and $\mathrm{y}$-amino-butyric acid, which are not present in milk proteins and might originate from early microbial metabolism. 
An increase $(P<0.01)$ of PP content of $20 \%$ was observed for all of the semi-skimmed milk samples, with respect to the corresponding parent whole milk (Fig. 2), as a result of plasmin activity taking place during gravity separation of fat. At the temperatures used (usually $10-16^{\circ} \mathrm{C}$ ), enzyme activities are not fully inhibited. This limited proteolysis, in combination with slight acidification, is considered to improve casein susceptibility to rennet coagulation (Resmini et al., 1982). In contrast, extensive plasmin activity in cheese milk caused an increased nitrogen loss in whey, although the nature of that fraction was not investigated (Mara et al., 1998). Hence, the pattern of SNCs in cheese milk can provide an explanation of unexpectedly anomalous behavior upon coagulation. Due to the bacteriological purification achieved (Dellaglio et al., 1969; Caplan et al., 2013), no further protein or peptide degradation occurred in milk and hence both SP and FAA levels remained almost unchanged (Fig. 2).

Considering that CMPs represent about 3\% of casein weight (Thoma et al., 2006) and that about $20 \%$ of CMPs are not released in Grana Padano coagulation (Resmini et al., 1982), the levels of CMPs we found in whey samples (Fig. 2) are consistent with what might be expected, although they were calculated using the same response factor at $205 \mathrm{~nm}$ as for $\alpha$-La. Due to the sharp increase in temperature during vat working and the parallel dehydration of casein micelle surface (O’Mahony \& Fox, 2013), enzymes likely only facilitate specific (primary) protein hydrolysis. It has been demonstrated (Sheehan et al., 2007; Masotti et al., 2010) that plasmin is not inactivated during in-vat processing, and is able to hydrolyze $\beta$-casein, even during ripening of cheeses cooked at high temperature, such as Grana Padano. However, the enzymatic activity did not occur during curd cooking, probably due to the progressive aggregation of casein micelles through strong hydrophobic interactions which may limit enzyme accessibility. The pattern we obtained for fresh 

that of the vat milk for all the individual casein fractions, but not for k-casein (not shown). Unexpectedly, the level of PP in whey was much lower $(P<0.01)$ than in the parent vat milk, whereas the level of SP was about twice as high (Fig. 2). The increase of SP derives from both the added WC and proteolytic activity of the most thermophilic LAB. Partial hydrolysis of PP cannot be excluded to explain the lower levels we found in the SW. Van Boekel and Crijns (1994) showed that, under laboratory conditions, the content of PP5 (the most hydrophobic among PP components) in rennet whey changes depending upon $\mathrm{pH}$ of milk at coagulation, and a possible association of this component with paracasein was hypothesized. Merin et al. (2008) report that addition of PP components to milk increased the clotting time and curd firmness. Nevertheless, no direct evidence is available in the literature for the selective retention of PP in cheese curd.

Preliminary results we obtained by CZE of Grana Padano cheese curd (not shown) point in this direction. However, further investigation is needed to clarify this aspect, which is of high practical interest as it directly affects cheese yield.

The content of FAA increased by $15-20 \%$ on average $(P<0.05)$, confirming that primary proteolysis mostly takes place in this step. Thermal conditions occurring during in-vat processing did not cause denaturation of $\alpha$-La and $\beta$-Lg (Fig. 2). From the HPLC chromatograms (Fig. 1), it can be seen that more heat-sensitive whey proteins, i.e. bovine serum albumin and immunoglobulins, not quantified in this study, did not undergo detectable denaturation. Besides whey proteins, the content of soluble nitrogen molecules in the SW from Grana Padano cheese-making accounted for retained in the extracted curd and will represent the initial nitrogen sources for LAB to grow during the molding time. 
The composition of SNCs changed dramatically during the whey fermentation process (Fig. 2). Lacking casein, SNCs represent a source of essential amino acids for LAB growth in whey. For the first time, the behavior of the individual components has been evaluated in this study along the same production process, from raw milk to the derived WC. This approach has allowed even minor changes to be highlighted and quantitatively evaluated. The most relevant finding was that $\alpha$-La was almost completely hydrolyzed whereas $\beta$-Lg remained intact. This aspect is currently under study, since published literature on the capability of LAB to degrade soluble whey proteins is contradictory. Differences in tested strains and growing conditions can partially explain discrepancies among studies (Bosi et al., 1990). Furthermore, to our knowledge no data are available on soluble whey protein pattern in natural WC for Grana Padano cheese-making and in natural starter cultures in general.

All non-protein SNCs were intensively degraded $(P<0.01)$. Residual traces of CMPs and PP were detected in WC, whereas the content of SP decreased by $40 \%$ on average but the range of values found was very wide. This pool of low-MW peptides originates from the proteolytic activity of LAB and hence individual peptides are continuously formed and hydrolyzed over time. Therefore, a defined pattern of these components can not be established and can not give reliable information on microbial growth behavior. In contrast, FAA represent more stable molecules, limited in number and directly related to LAB metabolic pathways. As a result of LAB growth, the FAA content increased by a factor 4 to 5 (Fig. 2). Recently, genomic studies are increasingly being used to clarify the proteolytic systems of LAB and to identify specific proteinase and peptidase activities relevant to cheese ripening (Liu et al., 2010; Broadbent et al., 2011). These studies will shed more 
light on LAB growth in whey as well. However, direct evidence of the enzymes actually involved can only be achieved by evaluating the FAA pattern modification.

The overall SNCS pattern we found in WC was fully confirmed on a larger number of samples collected at six other Grana Padano cheese factories (Fig. 3), covering a wider area of the production zone. The ranges of variation were the same as in Fig. 2 for all fractions, for the first time showing that the SNC composition in natural WC of Grana Padano is well-defined, despite the unavoidable variability in management conditions of the preparation process.

Finally, a time course study of the SW fermentation step was carried out. Two batches were considered from the same factory to include the day-to-day variability. As shown in Fig. 4, PP and SP were promptly hydrolyzed by LAB at the beginning of growth, since both represent more ready nitrogen sources with respect to $\alpha$-La and CMPs. Although the PP level dropped within the first two hours, reaching a plateau at around $100 \mathrm{mg} \mathrm{L}^{-1}$, SP level decreased more progressively throughout the whole fermentation process. This behavior is likely the result of the progressive hydrolysis of peptides into new ones, depending upon microbial protease and peptidase patterns, hence confirms that the SP fraction is not reliable in characterizing the WC. It must be mentioned that oligopeptide uptake systems have been identified in several LAB having different specificities (Mills \& Thomas, 1981; Slattery et al., 2010). However, these aspects have mainly been investigated in milk or cheese, whereas the specific growth conditions considered here, i.e. in a medium lacking in casein and obtained from a vat process which is highly stressing for these organisms, need dedicated studies. Hydrolysis of high MW components, namely $\alpha$-La and CMPs, only began after 3-4 $\mathrm{h}$ of fermentation when the $\mathrm{pH}$ of the environment decreased below 4 (Fig. 4a). The drop in $\mathrm{pH}$ undoubtedly plays a role in enabling proteases to attack $\alpha$-La, since it modifies the molecule conformation (O'Mahony \& Fox, 2013). The content of FAA showed an irregular 
behavior in the first 5-6 h, afterwards increasing linearly, and was approximately five times higher at the end of the incubation period. This increase may be partly attributed to cell lysis, although no clear evidence of this phenomenon during whey fermentation is available from the literature, since studies were mainly carried out in cheese or culture broth. Moreover, the mechanisms of biosynthesis and metabolism of amino acids in LAB are still unclear. We have analyzed single amino acids throughout whey fermentation and found that many of them behaved rather differently (Fig. 5). Amino acids that are essential to LAB (e.g. leucine, serine, threonine, tyrosine, methionine, arginine, glutamic acid), depending upon the species (Slattery et al., 2010; Broadbent et al., 2011; Liu et al., 2010), are promptly taken up from the FAA pool to support the initial growth phase. Some FAA are almost completely consumed within the first 2-3 hours, then start to accumulate (Figs. 5-a and -b) as a result of different metabolic requirements of various LAB species involved. After the initial uptake, free glutamic acid is released by the cells, but as soon as $\mathrm{pH}$ drops, it is decarboxylated to $\gamma$-amino butyric acid (Fig. 5-c). Arginine uptake looks to be $\mathrm{pH}$ dependent as well (Fig. 5-d). After the initial uptake it accumulates in whey. However, as the increase of acidity stresses the LAB, uptake starts again since arginine can be converted into citrulline by intracellular enzymatic pathways to increase acid resistance. Apparently citrulline is not released into the medium. Although confirmation with a larger number of samples is needed, these observations demonstrate the importance of FAA, even in a peptide-rich environment. This approach may contribute to understanding the complex amino acid biosynthetic and metabolic pathways of $L A B$. 
277 Individual SNCs have been evaluated for the first time throughout the whole manufacturing 278 process of Grana Padano cheese by using specific analytical methods. Natural creaming of raw 279 milk and in-vat working proved to be relevant steps of the process contributing substrates for LAB 280 to growth during subsequent whey fermentation. In particular, PP content increased by $25 \%$ 281 during the first step whereas SP almost doubled in the second step. Amongst whey proteins, $\beta$-Lg 282 remained stable throughout the whole manufacturing process, whereas $\alpha$-La was completely 283 hydrolyzed during whey fermentation. The evolution of the FAA pattern gave direct evidence for 284 specific $L A B$ activities and nutritional requirements. These results represent a useful complement 285 to existing microbiological data for understanding the complex phenomena occurring during 286 manufacturing of hard cheeses. Furthermore, our data may help to interpret the selective growth 287 of various LAB species in a changing substrate (milk, sweet whey, acid whey) leading to different 288 microbial balances throughout the process.

\section{Acknowledgements}

291 This activity has been developed within the FILIGRANA Project funded by the Italian Ministry of 292 Agricultural, Food and Forestry Policies (MiPAAF D.M. 25741/7303/11, 1.12.11). The authors wish 293 to thank Dr Alessandro Ranghetti for his precious contribution in the statistical treatment of data. 


\section{References}

Bertocchi, L., Vitali, A., Lacetera, N., Nardone, A., Varisco, G., \& Bernabucci, U. (2014). Seasonal variations in the composition of Holstein cow's milk and temperature-humidity index relationship. Animal, 8, 667-674.

Borreani, G., Coppa, M., Revello-Chion, A., Comino, L., Giaccone, D., Ferlay, A., \& Tabacco E. (2013). Effect of different feeding strategies in intensive dairy farming systems on milk fatty acid profiles, and implications on feeding costs in Italy. Journal of Dairy Science, 96, 68406855.

Bosi, F., Bottazzi, V., Vescovo, M., Scolari, G.L., Battistotti, B. \& Dellaglio, F. (1990). Lactic acid bacteria for Grana cheese production. Part I. Technological characterization of thermophilic rod lactic acid bacteria. Scienza e Tecnica Lattiero-casearia, 41, 105-136.

Broadbent, J.R., Cai, H., Larsen, R.L., Hughes, J.D., Welker, D.L., De Carvalho, V.G., Tompkins, T.A., Ardo, Y., Vogensen, F., De Lorentiis, A., Gatti, M., Neviani, E., \& Steele, J.L. (2011). Genetic diversity in proteolytic enzymes and amino acid metabolism among Lactobacillus helveticus strains. Journal of Dairy Science, 94, 4313-4328.

Caplan, Z., Melilli, C., \& Barbano, D.M. (2013). Gravity separation of fat, somatic cells, and bacteria in raw and pasteurized milks. Journal of Dairy Science, 96, 2011-2019.

Cattaneo, S., Hogenboom, J.A., Masotti, F., Rosi, V., Pellegrino, L., Resmini, P. (2008). Grated Grana Padano cheese: new hints on how to control quality and recognize imitations. Dairy Science \& Technology, 88, 595-605.

Cattaneo, S., Stuknyté M., Pellegrino L., De Noni I. (2014). Targeted peptides for the quantitative evaluation of casein plasminolysis in drinking milk. Food Chemistry 155, 179-185.

Csapò, J., Csapò-Kiss, Z., Stefler, J., Martin, T.G., \& Nemethy S. (1995). Influence of mastitis on Damino acid content of milk. Journal of Dairy Science, 78, 2375-2381. 
Cremonesi, P., Vanoni, L., Morandi, S., Silvetti, T., Castiglioni, B., \& Brasca, M. (2011). Development of a pentaplex PCR assay for the simultaneous detection of Streptococcus thermophilus, Lactobacillus delbrueckii ssp. bulgaricus, L. delbrueckii ssp. lactis, L. helveticus, L. fermentum in whey starter for Grana Padano cheese. International Journal of Food Microbiology, 146, 207-211.

Dellaglio, F., Stadhouders, J., \& Hup, G. 1969. Distribution of bacteria between the bottom, middle, and cream layers of creamed raw milk. Netherland Milk \& Dairy Journal, 23, 140-145.

De Noni, I., Pellegrino, L., Cattaneo, S., \& Resmini, P. (2007). HPLC of proteose peptones for evaluating ageing of packaged pasteurized milk. International Dairy Journal,17, 12-19.

European Commission, 2004. Regulation No 853/2004 laying down the specific hygiene rules for foods of animal origin. Official Journal L226, 26.6.2004, p 22.

European Parliament and Council, 2012. Regulation No $1151 / 2012$ on quality schemes for agricultural products and foodstuffs. Official Journal L343, 14.12.2012, p.1.

Gatti, M., Bottari, B., Lazzi, C., Neviani, E., \& Mucchetti, G. (2014). Invited review: Microbial evolution in raw-milk, long-ripened cheeses produced using natural whey starters. Journal of Dairy Science, 97, 1-19.

Gatti, M., Bernini, V., Lazzi, C., \& Neviani, E. (2006) Fluorescence microscopy for studying the viability of microorganisms in natural whey starters. Letters of Applied Microbiology, 42, 338343.

Giraffa, G., Rossetti, G., Mucchetti, G., Addeo, F., \& Neviani E. (1998). Influence of the temperature gradient on the growth of thermophilic lactobacilli used as natural starters in Grana cheese. Journal of Dairy Science, 81, 31-36. 
ISO Standard 13875:2005 (IDF 178: 2005) Liquid milk - Determination of acid-soluble betaLactoglobulin content - Reverse-phase HPLC method. Geneva, Switzerland: International Organization for Standardization.

ISO Standard 13903:2005 Animal feeding stuffs - Determination of amino acids content. Geneva, Switzerland: International Organization for Standardization.

Ismail, B., \& Nielsen, S. S. (2010). Plasmin protease in milk: Current knowledge and relevance to dairy industry. Journal of Dairy Science, 93, 4999-5009.

Liu, M., Bayjanov, J.R., Renckens, B., Nauta, A., \& Siezen, R.J. (2010). The proteolytic system of lactic acid bacteria revisited: a genomic comparison. BMC Genomics, 11, 36-51.

Mara, O., Roupie, C., Duffy, A., \& Kelly, A.L. (1998).The curd-forming properties of milk as affected by the action of plasmin. International Dairy Journal, 8, 807-812.

Masotti, F., Hogenboom, J.A., Rosi, V., De Noni, I., \& Pellegrino, L. (2010). Proteolysis indices related to cheese ripening and typicalness in PDO Grana Padano cheese. International Dairy Journal, 20, 352-359.

Merin, U., Fleminger, G., Komanowski, J., Silanikove, N., Bernstein, S., \& Leitner, G. (2008). Subclinical udder infection with Streptococcus dysgalactiae impairs milk coagulation properties: The emerging role of proteose peptones. Dairy Science \& Technology, 88, 407419.

Mills, O.E. \& Thomas, T.D. (1981). Nitrogen sources for growth of lactic Streptococci in milk. New Zealand Journal of Dairy Science and Technology, 16, 43-55.

Montel, M.C., Buchin, S., Mallet, A., Delbes-Paus, C., Vuitton, D.A., Desmasures, N., \& Berthier, F. (2014). Traditional cheeses: Rich and diverse microbiota with associated benefits. International Journal of Food Microbiology, 177, 136-154. 
O'Mahony, J.A., \& Fox, P.F. (2013). Milk proteins: introduction and historical aspects. In P.L.H. McSweeney \& P.F. Fox (Eds.). Advanced dairy chemistry, proteins: basic aspects (Vol. 1A, 4th edn., pp. 43-85). New York, NY, USA: Springer Science.

Pâquet, D. (1989). Revue bibliographique: la fraction proteose peptones du lait. Le Lait, 69, 1-21.

Pellegrino, L., Battelli, G., Resmini, P., Ferranti, P., Barone, F., \& Addeo, F. (1997). Effects of heat load gradient occurring in molding on characterization and ripening of Grana Padano. Le Lait, 77, 217-228.

Raats, D., Offek, M., Minz, D., \& Halpern, M. (2011). Molecular analysis of bacterial communities in raw cow milk and the impact of refrigeration on its structure and dynamics. Food Microbiology, 28, 465-471.

Resmini, P., Volonterio, G., Prati, F., Pazzaglia, C., \& Motti, G. (1982). Caratteristiche del latte e fenomeni rilevati in caldaia nella lavorazione a formaggio Grana-Padano. Scienza e Tecnica Lattiero-Casearia, 33, 229-264.

Rossetti, L., Fornasari, M., Gatti, M., Lazzi, C., Neviani E., \& Giraffa G. (2008). Grana Padano cheese whey starter: microbial composition and strain distribution. International Journal of Food Microbiology, 127, 168-171.

Santarelli, M., Gatti, M., Lazzi, C., Bernini V., Zapparoli G.A., \& Neviani E. (2008). Whey starter for Grana Padano cheese: effect of technological parameters on viability and composition of the microbial community. Journal of Dairy Science, 91, 883-891.

Schlimme, E., Clawin-Radecker, I., Einhoff, K., Kiesner, C., Lorenzen, P., Martin, D., Meisel, H., Molkentin, J., \& Precht, D. (1996). Studies on distinguishing features for evaluating heat treatment of milk. Kieler Milchwirtschaftliche Forschungsberichte, 48, 5-36. 
Sheehan, J., Oliveira, J.C., Kelly, A.L., \& Mc Sweeney, P.L.H. (2007). Effect of cook temperature on primary proteolysis and predicted residual chymosin activity of a semi-hard cheese manufactured using thermophilic cultures. International Dairy Journal, 17, 826-834.

Slattery, L., O'Callaghan, J., Fitzgerald, G.F., Beresford, T., \& Ross, R.P. (2010). Invited review: Lactobacillus helveticus - A thermophilic dairy starter related to gut bacteria. Journal of Dairy Science, 93, 4435-4454.

Stergiadis, S., Seal, C.J., Leifert, C., Eyre, M.D., Larsen, M.K., \& Butler, G. (2013). Variation in nutritionally relevant components in retail Jersey and Guernsey whole milk. Food Chemistry, $139,540-548$.

Thoma, C., Krause, I., \& Kulozik, U. (2006). Precipitation behavior of caseino-macropeptides and their simultaneous determination with whey proteins by RP-HPLC. International Dairy Journal, 16, 285-293.

van Boekel, M.A.J.S., Crijns, C.L. (1994). Behaviour of the proteose-peptone fraction during renneting of milk. Netherlands Milk \& Dairy Journal, 48, 117-126.

Wedholm, A., Larsen, L.B., Lindmark-Mansson, H., Karlsson, A.H., \& Andrén A. (2006). Effect of protein composition on the cheese-making properties of milk from individual dairy cows. Journal of Dairy Science, 89, 3296-3305. 
407 Table 1

408 Content of soluble $\beta$-lactoglobulin ( $\beta$-Lg), $\alpha$-lactalbumin $(\alpha$-La), proteose-peptones (PP), small

409 peptides (SP) and free amino acids (FAA) in raw milk samples collected at eight dairies producing 410 Grana Padano cheese in different seasons.

414

\begin{tabular}{|c|c|c|c|c|c|c|c|c|}
\hline & & $\begin{array}{r}\text { Spring / S } \\
n=1\end{array}$ & mmer & & & $\begin{array}{r}\text { Autumn / } \\
\mathrm{n}=9\end{array}$ & linter & 415 \\
\hline & $\underset{\left(\mathrm{mg} \mathrm{L}^{-1}\right)}{\operatorname{mean}}$ & $\underset{\left(\mathrm{mg} \mathrm{L}^{-1}\right)}{\min } \pm \mathrm{SD}^{\mathrm{a}}$ & $\underset{\left(\mathrm{mg} \mathrm{L}^{-1}\right)}{\max } \pm \mathrm{SD}$ & $\mathrm{CV}^{\mathrm{b}}$ & $\underset{\left(\mathrm{mg} \mathrm{L}^{-1}\right)}{\operatorname{mean}}$ & $\underset{\left(\mathrm{mg} \mathrm{L}^{-1}\right)}{\min } \pm \mathrm{SD}$ & $\underset{\left(\operatorname{mg~L}^{-1}\right)}{\max } \pm \mathrm{SD}$ & ${ }^{416} \mathrm{~V}$ \\
\hline & & & & & & & & \\
\hline$\beta-\operatorname{Lg}$ & 3438 & $3076 \pm 45$ & $3829 \pm 37$ & 8 & 3245 & $3073 \pm 51$ & $3910 \pm 30$ & 9 \\
\hline$\alpha-L a$ & 1152 & $1105 \pm 31$ & $1243 \pm 19$ & 3 & 1121 & $1056 \pm 31$ & $1199 \pm 28$ & $418_{4}$ \\
\hline PP & 502 & $281 \pm 25$ & $650 \pm 26$ & 24 & 457 & $193 \pm 30$ & $655 \pm 20$ & $416^{9}$ \\
\hline SP & 507 & $241 \pm 23$ & $722 \pm 19$ & 36 & 508 & $279 \pm 21$ & $595 \pm 22$ & \\
\hline FAA & 76 & $63 \pm 3$ & $90 \pm 4$ & 13 & 75 & $67 \pm 4$ & $89 \pm 5$ & 4200 \\
\hline
\end{tabular}

$422{ }^{a}$ SD: standard deviation.

$423{ }^{\mathrm{b}} \mathrm{CV}$ : coefficient of variation. 
425 Content of free amino acids in 24 samples of raw milk collected at eight dairies producing Grana 426 Padano cheese.

427

\begin{tabular}{|c|c|c|c|c|}
\hline & $\begin{array}{c}\text { mean } \\
\left(\mathrm{mg} \mathrm{L}^{-1}\right)\end{array}$ & $\underset{\left(m g L^{-1}\right)}{\min .} \pm D^{a}$ & $\underset{\left(m g L^{-1}\right)}{\max . \pm S D^{a}}$ & $C V^{b}$ \\
\hline Asp & 2.93 & $2.19 \pm 0.13$ & $3.38 \pm 0.17$ & 12 \\
\hline Thr & 1.43 & $1.18 \pm 0.07$ & $1.78 \pm 0.11$ & 11 \\
\hline Ser & 1.07 & $0.83 \pm 0.08$ & $1.44 \pm 0.09$ & 14 \\
\hline Asn & 0.27 & $n \cdot d^{c}$ & $0.53 \pm 0.05$ & 58 \\
\hline Glu & 42.97 & $35.3 \pm 1.4$ & $53.9 \pm 1.6$ & 13 \\
\hline Gln & 1.96 & $0.03 \pm 0.00$ & $5.09 \pm 0.25$ & 67 \\
\hline Gly & 6.75 & $4.98 \pm 0.30$ & $9.43 \pm 0.47$ & 16 \\
\hline Ala & 3.59 & $3.02 \pm 0.18$ & $4.15 \pm 0.21$ & 10 \\
\hline Cit & 0.81 & n.d. & $2.18 \pm 0.13$ & 79 \\
\hline Val & 2.18 & $1.02 \pm 0.06$ & $3.92 \pm 0.20$ & 44 \\
\hline Met & 0.09 & n.d. & $0.23 \pm 0.02$ & 89 \\
\hline Ile & 0.59 & $0.33 \pm 0.03$ & $0.88 \pm 0.09$ & 25 \\
\hline Leu & 0.86 & $0.42 \pm 0.04$ & $1.43 \pm 0.09$ & 37 \\
\hline Tyr & 0.63 & $0.05 \pm 0.00$ & $2.15 \pm 0.13$ & 62 \\
\hline Phe & 0.55 & $0.09 \pm 0.01$ & $0.90 \pm 0.09$ & 43 \\
\hline Gaba & 0.04 & n.d. & $0.25 \pm 0.03$ & 167 \\
\hline Orn & 0.61 & $0.47 \pm 0.05$ & $0.76 \pm 0.08$ & 12 \\
\hline Lys & 2.56 & $1.88 \pm 0.11$ & $3.27 \pm 0.16$ & 19 \\
\hline His & 0.45 & $0.24 \pm 0.02$ & $0.63 \pm 0.06$ & 22 \\
\hline Arg & 2.92 & $1.82 \pm 0.11$ & $3.64 \pm 0.18$ & 17 \\
\hline Pro & 2.29 & $1.86 \pm 0.11$ & $3.15 \pm 0.16$ & 13 \\
\hline
\end{tabular}

$429{ }^{b} \mathrm{CV}$ : coefficient of variation.

$430{ }^{\mathrm{c}}$ Not detectable.

431

432

433

434

435 


\section{Captions to figures}

Fig. 1. Typical HPLC patterns of soluble nitrogen compounds in samples of whole milk (WM), sweet whey (SW) and whey culture (WC). SP, small peptides; PP, proteose-peptones; $\alpha$-La, $\alpha$ lactalbumin; $\beta$-Lg, $\beta$-lactoglobulin; CMP, caseinomacropeptide; BSA, blood serum albumin; Ig, immunoglobulins.

Fig. 2. Evolution of the different fractions of soluble nitrogen compounds in whole milk (WM), 
tyrosine, phenylalanine; C: glutamic acid, glutamine, $\mathrm{v}$-amino butyric acid; D: arginine, ornithine, citrulline. 